\title{
Medya Siyaset Etkileşimi Bağlamında Türkiye'de Siyasetin Medya Alanındaki Düzenlemeleri Üzerine Bir İnceleme
}

\author{
Mustafa Akdağ (Prof. Dr.)
}

iD Erciyes Üniversitesi Illetişim Fakültesi makdag42@gmail.com

\author{
Başvuru Tarihi: 21.04.2020 \\ Yayına Kabul Tarihi: 13.07.2020 \\ Yayınlanma Tarihi: 24.07.2020 \\ https://doi.org/10.17680/erciyesiletisim.724441
}

\section{Öz}

Medya ve siyaset, kamusal hizmet yapan, toplum tarafından görevlendirilen alternatifsiz bir sistem olarak görülmektedir. İki kurumun da çalışmalarını, toplum adına yürüttüğünü söylemek mümkündür. Bu açıdan kaçınılmaz bir diyalektik ilişki içinde bulunan kurumlar, toplumsal sistemdeki ilişki ve etkileşimler, birbirine bakış açıları ve toplumsal çıktıları açllarından incelendiğinde sorumluluklarının bilincinde hareket etmelidir. Kitleleri bilgilendirmeyi ve buna bağlı olarak yönlendirme merkezlerini içine alan medya ile bu fonksiyonları kendi doğasından ve biraz da sistemden alan siyaset arasında her zaman bir işbirliği ve bunun yanı sıra bir çatışma söz konusudur. Her iki güç de yönlendirme ve bilgilendirmenin kendi tekelinde olmasını tercih etmekte ve zaman zaman bunu paylaşımla elde etmektedir. Dolayısıyla medya ve siyaset, her zaman ve her durumda sürekli etkileşim ve iletişim içinde olmak zorundadır. Sürekli etkileşimin getirdiği durumların değerlendirilmesi, insanların medyayı nasıl okuması veya nasıl görmesi gerektiği açısından önem taşımaktadır. Medyanın gerçekten haber verme ve kamuoyunu bilgilendirme fonksiyonu siyasetle ilişskisi bağlamında değerlendirilmelidir. Siyasetin istediği ya da öne sürdügü çalışmaları, faaliyetleri ulaştırmak için medyaya baskı yapmak amacıyla birtakım düzenlemeleri kullanması ve bu düzenlemeleri medyanın tepesinde bir kılıç gibi tutması medyanın tarafsızlığını ve objektif haber sunma gücünü zayıflatacaktır. Sonucunda siyaset tarafindan her zaman baskılanan ve çeşitli düzenlemelerle denetim altında tutulan, yeri geldiğinde propaganda aracı olarak kullanılan bir mecra ortaya çlkmaktadır.

Anahtar Kelimeler: İletişim, Medya, Siyaset, Medya ve Siyaset İlişkisi. 


\title{
A Review of Regulations of Politics in Media Field in Turkey in The Context of Media - Politics Interaction
}

\author{
Mustafa Akdağ (Prof. Dr.) \\ Erciyes University Faculty of Communication \\ makdag42@gmail.com
}

Date Received: 21.04.2020

Date Accepted: 13.07.2020

Date Published: 24.07.2020

https://doi.org/10.17680/erciyesiletisim.724441

\begin{abstract}
Media and politics are seen as a non-alternative system that provides public service and is assigned by the society. It is possible to say that both institutions carry out their work on behalf of the society. Institutions that have an inevitable dialectical relationship in this respect should act with the awareness of their responsibilities when examined in terms of relationships and interactions, perspectives and social outcomes within the social system. These functions inform the masses with their own nature and accordingly routing the media and some in the center from the system is subject to conflict as well as cooperation in the field of politics. Both powers prefer to have their own monopoly on guidance and information, and from time to time achieve this through sharing. Therefore, media and politics have to be in constant interaction and communication at all times and in all situations. Assessing situations brought about by constant interaction is important in terms of how people should read or view the media. The actual function of the media to inform and enlighten the public should be evaluated in the context of its relation to politics. The use of certain regulations in order to pressure the media to deliver the work or activities that politics wants or proposes, and to hold these regulations as a sword at the top of the media, will undermine the impartiality of the media and its power to deliver objective news.
\end{abstract}

Keywords: Communication, Media, Politics, Media and Politics Relationship. 


\section{Giriş}

Medya genel bir kavram olmakla beraber kitle iletişim araçlarının tümünü ifade eden bir yapıda kullanılmaktadır. Genellikle izleyici üzerinde etki oluşturmaya çalışan (Severin ve Tankard, 1994, s. 6) kitle iletişim araçları yine aynı şekilde hâkim ideolojiyi yaygınlaştıran etkili araçlar olarak değerlendirilmektedir (Yengin, 1996, s. 6). Dolayısıyla, insanlara kitlesel olarak hitap edebilmek, onları belli bir ürünün tüketimine yönlendirmek ve kendilerine sunulan belli düşünce ve görüşleri onaylamalarını sağlamak amacıyla faaliyet gösteren (Yaylagül, 2008, s. 15) medya, özellikle kitlelere bilgileri ulaştırmak, mesaj iletmek ve zamanlarını değerlendirmek gibi çeşitli işlevlerle hareket etmektedir. Taşkıran (2007, s. 18), kitle iletişiminin tanımlanabilmesi için işlevlerden yola çıkarak; kitle iletişimde gönderenin kurumsal bir yapısının olduğu, uzmanlaşmış grupların hedef kitleye sembolik içerikler gönderdiği, hedef kitlenin geniş, heterojen ve farklılaşmış bir mozaiğe sahip olduğu, kurumsal yapıların sembolik içerikleri aygıtlar yardımıyla yolladığı, bu aygıtların kitle iletişim araçları olarak ele alınan basın, radyo, televizyon, sinema vb. araçları kapsadığı, alıcı konumunda ise bireyin yer aldığı şeklinde çıkarımlar yapılabileceğini ifade etmektedir.

Zaman içinde toplumsal yapıların oluşmasının bir numaralı etkeni olmuş olan kitle iletişim araçları, düzen içinde pek çok güç elde etmiş ve bu güç sayesinde toplumda yeni dengelerin oluşmasında aktif roller oynamıştır (Kaya, 1985, s. 3). Bu aktif roller çerçevesinde Arabacı, bir takım sorulara yanıt aranması gerektiğini vurgulamaktadır: Medya hangi görevi yerine getirir veya getirmelidir? Temel görevini yapmaya çalışırken, yönetimden ne kadar etkilenmeli ya da yönetimden bağımsız olması mümkün müdür? Medya ne kadar özgür olmalıdır? Özgür olmayacak ise, varlığının nedeni ortadan kalkmış mıdır? Özgür olacaksa sınır olmalı mıdır? Olmalı ise, o sınırı kimler, ne hakla, nasıl çizeceklerdir? (2004, s. 105-106). Bu sorulara doğru cevaplar medya ve siyaset ilişkisinin daha net anlaşılmasını sağlayacaktır.

Dolayısıyla medya ve siyaset, kamusal hizmet yapan, toplum tarafından görevlendirilen alternatifsiz bir sistem olarak görülmektedir. İki kurum da çalışmaları, toplum adına yürüttüğünü söylemektedir. Bu açıdan kaçınılmaz bir diyalektik ilişki içinde bulunan kurumlar, toplumsal sistemdeki ilişki ve etkileşimler, birbirine bakış açları ve toplumsal çıktıları açılarından incelenebilir (Damlapınar, 2007, s. 116)

$\mathrm{Bu}$ ilişki çerçevesinde bakıldığında medya, siyasal iktidara haber kaynağı ve maddi açılardan bağlıdır. Siyasal iktidar da faaliyetlerinin duyurulması ve kamuoyunda kendini ifade edebilmek için medyaya ihtiyaç duymaktadır. Aralarında oluşan diyalektik ilişki farklı boyutlara taşındığında, her iki kurumun da asıl misyon ve amaçlarının dışına çıkılmakta ve çıkar ilişkilerine dönülmektedir. Aslında her iki kurumda birbirine bağımlıdır. Birbirinden ayrı düşünülemez. Medyanın meşruluğu da siyasetin meşruluğu da kabul görmeyle ortaya çıkmaktadır. İşte bu süreçte benimseme ve argümanlarını kabul ettirme noktasında birbirlerine ihtiyaç duymaktadırlar. Medi@Ware ${ }^{1}$ Projesi kapsamında hazırlandıktan sonra genişletilerek güncellenen bu çalışma, medya ve siyaset üzerine siyasal iktidarların meşruluğu ve medya aidiyet yapılarını iyi irdelemek yapılan tartışmanın doğru okunmasını sağlayabilir. Dolayısıyla çalışmanın temel amacı, her iki kurum arasındaki ilişkinin açıklanması ve hangi boyutlarda birbirlerine müdahale edildiği ve siyasetin bu anlamda daha baskın olduğu, elindeki argümanları kullanarak birtakım düzenlemeler vasıtasıyla medyayı nasıl tahakküm altına aldığı soruları üzerinden cevap bulunmaya çalışılacaktır. 


\section{Medya ve Siyaset İlişkisi}

Doğrudan doğruya siyasal olguları, bireylerin ve grupların davranış biçimlerini ele alarak aralarındaki ilişkileri ve sebep sonuç bağlarını meydana çıkarmak amacını hedefleyen bir sosyal bilim niteliği kazanan (Kapani, 1997, s. 26-27) siyaset, insanların yaşamlarını düzene koyan, temel kaideleri meydana getirmek, korumak ve değiștirmek amaciyla gerçekleştiren faaliyetlerin tamamıdır (Balcı, Tarhan, \& Bal, 2013, s. 23). Bir başka görüşe ve anlayışa göre siyaset, toplumda bulunan insanlar arasında bir çatışma, bir mücadele ve kavgadır. İnsanlar doğaları gereği, sosyal ve ekonomik durumları açısından farklı düşüncelere ve menfaatlere sahiptirler. Bu çeşitli düşünceler ve menfaatlerin farklılaşmasından oluşan çatışma, siyasetin temelini meydana getirmektedir (Kapani, 1997, s. 17).

Siyaset kavramının temellerini iktidara yönelik faaliyetler oluşturmaktadır. İktidar kavramının olduğu her yerde siyasetten söz edilebilir (Demir, 2018, s. 81). Siyaset bu şekilde tanımlanırken medya; basılı, görsel ve ișitsel araçlardan meydana gelen haber alma ve aktarma, eğitme ve eğlendirme, duygu ve düşünceleri aktarma, kamuoyunu bilgilendirme ve oluşturma ișlevlerine sahip olan iletișim kanalı ve mecrası olarak tanımlanabilir.

Medya ve siyaset arasındaki ilişki “ortak yaşama ilişkisi” şeklinde tanımlanmaktadır. Medya haber kaynağı olarak siyaseti görmekte; siyasiler ise kendi düşünce ve tutumlarının kamuoyuna ulaşmasını istemektedir. Bu bakımdan her ikisinin de gereksinmeleri genel itibariyle uyum içerisindedir (Yüksel, 2001, s. 143). Elbette bu ilişki karşılıklıdır. Fakat kuşatıcı çevreyi oluşturan, medyadan çok siyasettir. Onun için denilebilir ki, nasıl bir siyasi rejim var ise medya da öyle gelişmektedir. Hiçbir medya sistemi asla siyasi rejimden bağımsız olamaz (Arabacı, 2004, s. 109)

Kitleleri bilgilendirmeyi ve buna bağlı olarak yönlendirme merkezlerini içine alan medya ile bu fonksiyonları kendi doğasından ve biraz da sistemden alan siyaset arasında her zaman bir işbirliği ve bunun yanı sıra bir çatışma söz konusudur. Her iki güç de yönlendirme ve bilgilendirmenin kendi tekelinde olmasını tercih etmekte ve zaman zaman bunu paylaşımla elde etmektedir. Fakat bazen bu, sorunlara yol açmaktadır. Medya, siyaseti kendi alt sistemi haline getirmek için çaba içindeyken, tamamen aynı istikamette olarak siyasette medya için aynı duyguları beslemektedir (Hazar, 2008, s. 254).

Medya açısından bakıldığında; temel olan etkili olmaktır. Bu etki alanı da kamuoyunda güçlü olmaktan, inandırıcı olmaktan geçmektedir. Kamuoyunun bilgilendirilmesi, yönlendirilmesi ve istenildiği gibi harekete geçirilmesi medyanın siyaset üzerindeki etkisini göstermek adına önem taşımaktadır. Güz'e göre; kitle iletişim araçlarının bağımsız bir şekilde ve etkilenmeden hareket edebilmeleri; toplumun bu araçlardan beklentileri ve siyasal sistem içerisinde bu araçlara yüklenen görev ve sorumluluk açısından önemlidir. Bağımsız ya da objektif hareket edemeyen kitle iletişim araçlarına toplumun saygı duyması ve güvenmesi mümkün değildir. Bu bağlamda, kitle iletişim araçlarının yansız ve objektif hareket edemedikleri düşüncesi siyasal sistemin sağlıklı işlemesi bakımından sakıncalar doğurabilir. Demokratik sistemlerde siyasal sistemin sağlıklı bir şekilde yürütülmesi kitle iletişim araçları ile toplum arasındaki düzenli ilişkilerin oluşturulması ve yürütülmesiyle mümkündür. Kitle iletişim araçlarının yanlı haber sunduğuyla ilgili bir kanaatin oluşması bu araçların siyasal kişi, kurum ya da kuruluşlarla ilgili vereceği haberlerin de inandırıcılığını yitirmesine sebep olacaktır (2005, s. 88). 
Burton, medya ile siyaset arasındaki ilişkinin, güçleri dolayısıyla kıskançlık düzeyinde olduğunu söylemektedir. Siyasiler, temsil ettikleri halk adına, medyanın istediğini söylemesini ve yapmasını engellemeye çalışırken, medya ise, halkı temsil ettiğini ve bu baskıcı güçten kurtulmak istediğini vurgulamaktadır. Bu iki güç arasındaki ilişki noktaları şöyle uyarlanabilir (Yüksel, 2001, s. 144-145):

- Kanun: Belirli kanunlar çerçevesinde kendi bilgi ve çalışmalarını korumaya yönelik hareket eden siyasi iktidarın birçok organı, medya ve onun meydana gelen olayları söyleme hakkı ile çatışır.

- Basın Toplantıları ve Basın Açıklamaları: Hükümet organları medyadaki haber sunanların temel bilgi alma kaynaklarıdır. Bu açıdan, haber değeri olan bilgilere ihtiyaç duyulduğunda, haberciler hükümet kaynaklarının eline düşerler.

- Lobi Calışmaları: Siyasi gruplar medya mensupların kızdığı bu yolu kullanırlar ve kendilerine yakın isimleri sürekli göz önünde bulundururlar.

- Finans: Medya, siyasi iktidardan vergi ve gümrük indirimi, kâğıt desteği vb. teşviklerle önemli finans desteği alabilir.

- Doğrudan Kontrol: Siyasi iktidar, medya yayınlarını çeşitli birimleri aracılığıyla kontrol edebilmektedir.

- Dolaylı Kontrol: Genelde ortaya konulması güç olan bir durum olsa da, hükümet ve medya arasında bir sürtüşme olduğu dönemlerde görülen değişik dolaylı kontrol araçlarından söz edilebilmektedir.

- Medyada Boy Göstermek: Siyasi iktidar mensuplarının medyada boy göstermesi bu iki kurumun yarar sağlamasına güzel bir örnektir. Yayın yapanlar, bilgi kaynaklarına geçerlilik kazandıran kişiler olarak siyasilere ve siyasiler de partileri kadar seçmenleri gözünde itibar görebilmek için buna ihtiyaç duyarlar.

- Partilerin Siyasi Yayınları: Siyasi partiler bunu bir hak olarak isteyebilirler. Özellikle seçim zamanlarında televizyonlarda yayınlanan konuşma veya haber sürelerinin paylaşımı konularındaki tartışmalar buna örnek verilebilir.

Dolayısıyla, medya kamuoyu aracılığıyla siyasetle ilgilenmektedir. Bir başka deyişle, bütün demokratik sistemlerde kamuoyunun temayülleri büyük önem taşımaktadır. Çoğulcu demokratik sistemlerde kamuoyu çok yönlü etkiler altında meydana gelmekte ve yöneticilerin kararlarını önemli ölçüde etkilemektedir. Fakat totaliter rejimlerde kamuoyunu tek yönlü oluşturmak için bütün imkânlar seferber edilmektedir. Baskıcı olarak da adlandırılan rejimlerde kamuoyu, siyasi iktidarın eliyle oluşturulmaktadır (Taşdelen, 1997, s. 195). Bu anlamda ise dünya genelinde siyasi rejimler ve bu rejimlerde yer alan medya sistemlerine değinmek, medya ve siyaset ilişkisini anlamak adına gereklidir.

\section{Medya ve Siyaset İlişkisinde Kuramlar}

Medya ve siyaset ilişkisi bağlamında kuramlar, medyanın siyasi yönetimlerde görevini nasıl yaptığını ortaya koymak amacıyla ele alınmaktadır. Siyasetin yönetim tarzına göre medyanın işleyişi, pozisyonu, yöntemi tamamen farklılaşabilmektedir. Medyanın haber verme ve bilgilendirme işlevlerinin yanında kamuoyu oluşturma ve eğitme gibi işlevleri de siyasi yönetimlere göre yeniden şekillenmektedir. Siyasal yönetimlerin baskıcı ve otoriter anlayışlarına uygun olarak medyanın iktidarın istediği bilgi ve haberleri sunması söz konusu iken demokratik bir tarzda oluşan siyasal anlayışların da medyaya daha özgürlükçü yaklaștığını söylemek mümkündür. İktidarların yönetim yaklaşımlarıyla bu 
medya bakışları Siebert, Peterson, \& Schramm tarafından normatif medya kuramları olarak ele alınmış ve McQuail ise bu kuramlara iki yeni kuram ilave ederek medya ve siyaset ilişkini altı kuram açısından değerlendirmiştir.

$\mathrm{Bu}$ anlamda medya ve siyaset ilişkisi açısından normatif medya kuramları olarak da adlandırlan kuramlar; Otoriter, Liberal, Toplumsal Sorumluluk ve Sovyet (Siebert, Peterson, \& Schramm, 1963)/totaliter medya adı altında dört başlıkta ele alınmaktadır:

\subsection{Otoriter Medya Kuramı}

Kuram, medyanın kontrolün sadece otorite eliyle olmasını, herhangi bir şekilde otoriteyi zayıflatıcı veya eleștirici haber veya yayın yapmamasını temel almaktadır. Medyanın sınırlandırılması için otoriteyi elinde bulunduranlara gerekli ortamı oluşturan kuram tarihsel ve coğrafi olarak en yaygın olma özelliğine sahiptir. Kuramın temel prensipleri şöyledir:

- Medya kuruluşları, kanunları ya da kurulu düzeni bozmaya yönelik yayın yapmaktan kaçınmak zorundadır.

- Medya, yönetime sahip bulunan otoriteye bağlı olmalıdır.

- Medya, siyasi ve ahlaki değerlere ve çoğunluğa karşı olmamalıdır. Kurama göre, kuralları uygulamak için sansür uygulanabilir.

- Mevcut otoriteye karşı çıkma, kabullenilene saldırma, resmi politikaya sataşma ya da moral değerlere saldırı suç değerlendirilmesi olarak görülmektedir.

- İletişimciler kendi medya kuruluşları içinde bağımsızdırlar.

\subsection{Liberal Medya Kuramı}

Liberal düşünceye göre insan akılcı bir varlıktır. Devletin amacı, bireylerin mutluluğunu sağlamak ve menfaatlerini gözetmektir. Liberal düşünce yapısında gerçeğe ulaştıracak yol bir bataklıktan geçebilir. Fakat yolun sonunda akılcı bir varlık olan insan, kabul edebileceği ve belgelendireceği kesin gerçeklere ulaşabilmektedir. $\mathrm{Bu}$ düşünceden beslenen liberal medya kuramı, kişilerin istedikleri şeyleri yayınlayabilme konusunda özgür olmasını kabul etmektedir. Bu bir anlamda düşünce, ifade, örgütlenme, toplantı hak ve özgürlüklerinin bir uzantısı olarak liberal demokratik sistemle örtüşmektedir. Liberal medya, toplumdaki çeşitli bireylerin istek ve ihtiyaçlarını tatmin edebilmektedir. Medya organlarına müdahale, düşüncenin ve toplumun gerçeğe ve doğruya ulaşmasını engellemektedir.

Kurama göre, doğruluk, özgürlük ve menfaat beraber yürümeli, medyanın korunması ancak mantıksız işler ortaya çıkınca söz konusu olmalıdır. Medyaya sansür uygulanmamalıdır. Fakat kanunlara karşı gelinmesi, kişi haklarının ihlali gibi durumlarda mağdur kişi ve kurumlar için yasal güvencenin sağlanması zaruri hale gelmektedir. Bireyin, azınlıkların korunması ve devlet ciddiyeti gibi durumların konu edilmemesi çoğu insan için medya hürriyetinden önce gelmektedir. Kuramı şekillendiren temel ilkeler şu şekildedir:

- Medya üçüncü bir oluşum tarafından sansür edilmemelidir.

- Yayın yapma ve dağıtım için ruhsat ya da önceden izin alma zorunluluğu olmaksızın, yayıncılık her ferde ve topluluğa açık olmalıdır.

- Hükümete, bürokratlara veya partilere yönelik saldırılar, cezaya tabi tutulmalıdır.

- Yayınlanacak enformasyon noktasında sınırlama olmamalıdır. 
- Düşünce ve kanaatler çerçevesinde doğru ve yanlışın karşılaştırılması için bir ortam oluşturulmalıdır.

- Yayınlanacak enformasyonun toplanması birtakım kurallarla sinırlandırılmamalıdır.

- Uluslararası medya ile ilişkili enformasyon alışverişi, herhangi bir sınırlamaya tabi tutulmamalıdır.

- İletişimciler kendi aralarında otonomi oluşturabilmelidirler.

\subsection{Toplumsal Sorumluluk Kuramı}

Hutchins Komisyonu, 1947 yılında A Free and Responsible Press (Özgür ve Sorumlu bir Basın] adlı rapor yayınlamış ve liberal medya işleyişinde oluşan aksaklıkların iyileştirilebilmesi için ne tür önlemler alınması gerektiği hususunda görüşlerini bildirmişlerdir. $\mathrm{Bu}$ anlamda Toplumsal Sorumluluk Kuramı, liberal sistemin birtakım önemli konularda basın özgürlüğü vaadini ve toplumun beklentilerini yerine getirmedeki başarısızlığı üzerine ortaya çıkmıştır. Kuram, toplumsal görev ile bağımsızlığı bağdaştırmaktadır. Mülkiyet olarak özel kişi ya da kuruluşlara ait olan medya kuruluşları yalnızca hedef kitle ve medya patronlarına karşı değil, geniş oranda topluma karşı sorumludur. Bireysel özgürlükler ve seçim, medya özgürlüğü ve medyanın topluma karşı görevleri açısından üç prensibi uzlaştırmaya çalışan kuramın temel ilkeleri şu şekildedir:

- Medya kuruluşları topluma karşı birtakım görevleri olduğunu kabul ederek bunları yerine getirmelidir.

- Bu görevler yapılırken bilgi verici olma, gerçeklik, doğruluk, nesnellik gibi standartlar göz önünde tutulmalıdır.

- Medya kanunlar çerçevesinde kendi kendisini sınırlandırıcı ve düzenleyici olmak durumundadır.

- Medya kuruluşları suça, şiddete ve toplumsal karışıklığa neden olabilecek ya da azınlıklara saldırı niteliği taşıyan yayınlardan uzak durmalıdır.

- Medya çoğulcu olmalı, toplumsal farklılıkları, farklı görüşlere yer vererek ve aynı zamanda cevap ve düzeltme hakkı tanıyarak ortadan kaldırmalıdır.

- Toplum, medyadan yüksek bir çalışma temposu bekleme gücüne sahiptir ve medya beklentileri yerine getirilmez ise kamu yararı için müdahale kaçınılmaz olmaktadır.

- İletişimciler ve medya uzmanları işverenlere ve pazara olduğu gibi topluma karşı da sorumludurlar.

\subsection{Sovyet/Totaliter Medya Kuramı}

Marksist düşünceyle yoğrulan ve 1917 Rus devrimiyle şekillenen kurama göre bütün medya kuruluşları, başta komünist parti olmak üzere işçi sınıfının temsilcileri tarafından kontrole tabi tutulmaktadır. Mutlak özgürlük mümkün değildir. Sosyalist toplumda sınıf çatışmaları bulunmadığı için medya da ona göre hareket etmek durumunda kalır ve yayın politikalarını politik çatışmalardan uzak olarak düzenlemektedir. Sosyalist medya kar amacı gütmez. Burada önemli bir faktör olarak da medya, toplumun şekillenmesinde, sosyalleşmede, gayri resmi sosyal kontrolde ve planlanmış ekonomik amaçlara doğru toplumun yönlendirilmesinde önemli rol üstlenmektedir. Kuram, medyanın siyasi organlar tarafından kontrolünü kabul eder ve diğer farklı durumlarda siyasi hayatın diğer araçları ile iç içe olmasını sağlamaktadır. Kuramın temel varsayımları șunlardır: 
- Medya işçi sınıfının menfaatlerine hizmet etmeli ve onları kontrol altında tutmalı, özel mülkiyet altında olmamalıdır.

- Medya sosyalleștirme, eğitim, bilgi, motivasyon, seferberlik vb. şekilde toplum için pozitif olan amaçlara hizmet için var olmalıdır.

- Topluma karşı yerine getirilmesi gereken görevleri yanı sıra medya, hedef kitlesinin istek ve gereksinmelerine de cevap vermek durumundadır.

- Toplum karşıtı yayınlarından dolayı toplumun medyaya sansür uygulama ve gerekli yasal düzenlemeleri yapma yetkisi bulunmaktadır.

- İlkeler doğrultusunda medyada, dünya ve toplumun tam ve objektif görüşü aktarılmalıdır.

- Medya mensupları, amaç ve idealleri toplumun menfaatleriyle uyuşan sorumlu profesyonellerdir.

- Medya ülke içinde ve dışındaki ilerici hareketleri desteklemek durumundadır.

McQuail bu dört kurama ilave olarak Gelişme Aracı ve Katılımcı Demokratik Medya (McQuail, 1994) Kuramı ele alarak normatif medya kuramlarını altıya çıkarmaktadır.

\subsection{Gelişme Aracı Kuramı}

Kurama göre iletişim araçlarının kurulması ile ilgili olarak İnsan Hakları Evrensel Beyannamesi'nin 19. Maddesi temel teşkil etmektedir. Bu maddeye göre; herkes düşünce hürriyetine sahiptir ve bunu açıklama hakkına sahip olmalıdır. Bu hak herhangi bir müdahale olmaksızın fikirleri taşıma, bilgi ve fikirleri bir iletișim aracı aracılığıyla özgürce araştırma, alma ve söyleme özgürlügünü içermektedir. Gelişme aracı kuramına temel olan özellik, ekonomik ve sosyal gelişmenin kabul edilmesi ve bu gelişme ile etkileşimde olan ulusal yapılanmadır ve ulusal yapılanma için iletişimcilerin özgürlükleri onların sorumluluklarına indirgenir. Kuramda, bireysel özgürlüklerden daha çok sosyal amaçlar üzerinde durulmaktadır. Kuramın temel ilkeleri şu şekilde sıralanabilir:

- Medya milli politika ile ilgili aynı alanda pozitif gelişme görevini kabul ederek bu görevi yerine getirmelidir.

- Medyanın özgürlüğü, ekonomik öncelikler ve toplumun gelişme gereksinimlerine göre kısıtlamaya açık olmalıdır.

- Medya, içeriklerinde sosyal kültüre ve dile öncelik tanımalıdır.

- Medya çalışanları ve diğer mensupları enformasyonu toplama hakkı kadar bu hakkın getirmiş olduğu sorumluluğa da sahip olmalıdırlar.

- Devlet, gelişme politikaları doğrultusunda medya işlevlerine müdahale edebilir, kısitlayabilir, denetim ve kontrol yapabilir.

\subsection{Katılımcı Demokratik Medya Kuramı}

Bireylerin bilgi edinme özgürlüğünü merkeze alan Katılımcı Demokratik Medya Kuramının temel hareket noktası; merkezileşmiş, tekeller altına girmiş, izleyicisine/ okuruna egemen hale gelmiş medyayı reddetmesidir. Çoğulculuğu, daha küçük gruplar şeklinde örgütlenmeyi, yerelliği, kurumsallaşmamayı, enformasyon kaynak ve amacının değișebilirliğini, toplumun bütününde iletişimin yatay örgütlenmesini ve etki altına almamayı kabul etmektedir. Özgürlüğü esas alan bu kuramın temel ilkeleri şöyle sıralanabilir: 
- Bireyler ve azınlık gruplarının iletişim hakları bulunmaktadır ve kendilerinin belirleyecekleri gereksinimlerini medya kurumlarından isteme hakları mevcuttur.

- Medyanın yapılanması ve içeriğinin meydana gelmesi merkezi hükümetin ya da yönetimin bürokratik denetimine tabi olmamalıdır.

- Medya kuruluşları, medya mensupları için değil; izleyici, dinleyici ve hedef kitleleri için var olmalıdır.

- Gruplar, organizasyonlar ve yerel toplumlar seslerini duyurabilmek için kendi medyalarına sahip olmalıdır.

- Küçük çaplı, karşılıklı etkileşimci ve katılımcı medya yapıları daha geniş çaplı ve tek yönlü iletişim temin eden profesyonel medyadan daha iyidir.

- Medya kuruluşları ile ilgili toplumsal gereksinimler, bireysel tüketici talepleriyle yeterince açıklanamadığı gibi devlet ve ona bağlı kurumlar tarafından da açıklanamaz.

- İletişim, profesyonellere terk edilemeyecek kadar önem taşıyan bir unsurdur (akt. Güz, 2005, s. 17-25).

\section{Medya ve Siyaset ílişkisinde Medyanın Yeri}

Toplumsal sistemin önemli bir etkeni olarak medyanın, siyasal olgular, olaylar, tartışmalı konular, kurumlar ve aktörler hakkında toplumsal/kamusal algılamayı etkileme gücü, imaj çağının yükselişi ile beraber kendisini daha çok hissettirmeye başlamaktadır. Günümüzde, siyasetin medya üzerinden meydana gelmesi ve toplumsal kanaatlerin belirlenmesi, kurumlara mal edilen toplumsal güvenirliği de etkileme gücüne sahip (Damlapınar, 2008, s. 187) olan medya da siyasal iktidarın durumuna göre hareket etmektedir. Çok hızlı bir şekilde topluma ulaşabilen, toplumu harekete geçirebilen ve ikna gücünü kullanarak siyaseti yönlendirmek isteyen medya, siyaseti sıkı bir şekilde takip etmektedir. $\mathrm{Bu}$ anlamda, medyadaki hızlı teknolojik gelişim, medyanın gücünü arttırmakta bu durum ise medyayı ulaşılmaz kılmaktadır.

Kitle toplumunun şartlarında yeniden üretilmesine ihtiyaç duyulan politik ilişkilerin bir teknolojisi olarak gündeme dâhil olan (Bostancl, 1998, s. 161) medyanın, bu gücünü görebilen siyasi aktörler bunu kendilerini topluma anlatabilmek için tercih edebilirler. Burada önemli olan medyanın bu güç ile siyaseti yönlendirebilecek, etkileyebilecek seviyeye ulaşıp ulaşmadığı sorusudur. Bu sorunun cevabı medyanın siyaset üzerindeki etkisini anlamak adına önemlidir. $\mathrm{Bu}$ anlamda medyanın gücünü aldığı unsurlar; kamuoyunu oluşturmak için gündemi kontrol etmesi ve oluşturması, tekelleşerek hatta daha da ileri giderek kartel ${ }^{2}$ oluşturması ve kamu adına denetim görevi üstlenmesi ve araştırma gazeteciliği olarak ele alınabilir.

\subsection{Baskı Unsuru Olarak Gündem Olușturma}

Medyanın kamu gündemini belirlediği yolundaki düşünceleri ortaya atan 1920'lerde Walter Lippman'dır. Bernard Cohen'in medya çoğu zaman insanlara ne düşüneceklerini söylemede son derece başarılıdır sözleri gündem belirleme düşüncesinin özeti gibidir. $\mathrm{Bu}$ anlamda ilk eser ise Mc Combs ve Shaw'a ait olan "The Agenda-Setting Function of the Mass Media"dır (Yüksel, 2000, s. 6). Severin ve Tankard'a göre ise, medyanın halk üzerinde etkili olabileceğinin ele alındığı yollardan biri olan gündem oluşturma, medyanın ileteceği mesajları sunuş yoluyla, dinleyici ya da izleyicinin düşündüğü ve konuştuğu konuları belirlediği düşüncesine dayanmaktadır (1994, s. 364). Bir konuyu siyasi gündeme neyin yerleştirdiği sorusunu cevaplayan siyasal gündem araștırmaları için Rogers ve Dearing, 
bu araştırmaların üç genellemeye ulaştığından bahsetmektedir. Bunlar (Yüksel, 2001, s. 147-148);

- Medya gündemi tarafından meydana getirilen veya yansıtılan kamu gündemi, seçkin karar vericilerin ve bazı durumlarda siyasal yürütme planının da siyasal gündemini etkiler.

- Medya gündemi, siyasal gündem üzerinde doğrudan ve bazen güçlü etkilere sahiptir.

- Bazı konular içinse, medya üzerinde siyasal gündem doğrudan ve bazen güçlü etkilere sahiptir.

Hawthorne’a göre politikaların çevresini saran belirsizliği belirginleştirmede ve belirsizliğin oluşturduğu politika boşluğunu dolduracak alternatifleri halka açmada önemli görev üstlenebilen medya, belli programları meşrulaştırabilmekte ya da onları zora sokabilmektedir. Konuları değerlendirirken aktif ve pasif tutumlar içinde bulunması da gündemi çeşitli biçimlerde etkilemekte olan medyanın, siyasal gündemin oluşturulması aşamasında çok çeşitli roller üstlenebildiği bir gerçektir. Medya, olaylar ve hikâyeler üretirken eş zamanlı olarak olayları haberleștirerek aktif bir rol üstlenmektedir. Var olan enformasyonu toplama ve yeni enformasyon aktarımından daha da ileri giderek, hangi konuların politik gündemin bir parçası olacağına karar vermekte ve diğer politik aktörlerin yapabileceği gibi, gündemleri etkileyerek siyaset sahnesinde politik oyuncular haline gelebilmektedir. Böylece medya, yalnızca bazı konularda ön plana çıkarak gündemi belirlemekle kalmamakta, aynı zamanda politika sürecinin doğasını ve eylemlerini de etkilemiş olmaktadır (Terkan, 2005, s. 16-17).

Siyasi iktidarın kendini güçlü göstermek için kamuoyuna başvurması, kamuoyunu arkasına alması ve medyanın kamuoyunu yönlendirmesinin kendi lehine sonuçlanması gibi temel faktörler, medyanın yol haritasını belirlemesi için gereklidir. Siyasi düşünce ve kadroların tamamen halkın desteğini arkasına aldıklarında medya bu sürece aykırı davranmak istemeyecektir. Çünkü medya sahiplerinin sadece ve sadece medya kanalları yoktur ve genel itibariyle birçok sektörde destek isteyen işleri veya kuruluşları bulunmaktadır. Siyasi güç aleyhine davrandıkları ve söylemlerini geliştirdikleri sürece, siyasi birçok karardan etkilenebilecekleri gibi arkalarında destekçi bulunan kamuoyunun güvenini kaybetme durumuyla karşı karşıya kalabileceklerdir. Kamuoyunun ne düşündüğü, yapılan işler ile ilgili yorumları, desteklerinin devam edip etmediğiyle ilgili yollardan biri de kamuoyu yoklamalarıdır.

Kamuoyu Yoklamaları: Schiller'e göre kamuoyu yoklamaları, zihinlerin yönlendirilmesi, insanların belli biçimlerde düşüncesinin sağlanması açısından önem taşımaktadır. Amacı ise kişilerin belirli konularla ilgili düşüncelerinin belirlenmesi, alışkanlıklarının ve tercihlerinin tespitini sağlamaktır. Temel amaç ise, halkın düşüncelerinin arzu edilen biçimde oluşturulması ve belirlenen amaçlar doğrultusunda şekillendirilmesidir (Taşdelen, 1997, s. 197). Medyada her zaman aynı durum söz konusu değildir. Kitlelerin her zaman okunamayacağı, yapılan kamuoyu araştırması vb. çalışmaların istenilen sonucu veremeyeceği hususunda Laughey, kamuoyunun duygu, beğeni ve hallerinin ölçülmesinin oldukça güç olabileceğinden, çünkü fazlasıyla derin, genellikle örüntülü ve daima öngörülemez olabileceğinden söz etmektedir (2010, s. 39-40). Buna rağmen, medyanın kişilerin siyasal tutumlarını değiștirdiğini, halkın siyasal olaylar ve aktörler hakkında düșünüp hissettiklerini etkilediğini söyleyen araştırmalara rastlamak mümkündür (Milburn, 1998, s. 257). Kamuoyu araştırmaları tutum, davranış, beklenti, eğilim, yönelim ve düşünceleri ortaya çıkarabilmek amacıyla belli bir zaman dilimine sıkıșıp kalmaksızın 
yapılabilmektedir. Çıkan sonuçların kamuoyuna açıklanması araştırma yapılması kadar önem taşımaktadır (Güz, 2005, s. 97).

Toplumla ilişkiler bağlamında kamuoyu araștırmalarına ilgi gösteren medya kuruluşları, kamuoyunun eğilimi ne yönde, kendi yayın politikalarına bakışları nasıl olduğunu ve rakiplerinin durumunu öğrenmek amacıyla kamuoyu araştırmalarını takip etmektedirler. Araştırma neticelerinin iyi birer haber olma özelliği sergilemeleri medya kuruluşlarını kamuoyu araştırması yapmaya ya da yaptırmaya, yapılan araştırmanın neticelerine sayfalarında yer vermeye yöneltmektedir (Güz, 2005, s. 103). Kamuoyu araştırmaları, halkın gündemini öğrenmek, bu doğrultuda politikalar geliştirmek açısından siyasiler tarafından önemsenmekte ve sürekli olarak kamuoyu bu araştırmalar ile takip edilmektedir. Dolayısıyla eğilimlerin öğrenilmesi ve bu doğrultuda çalışmaların şekillendirilmesi medya kanalıyla aktarılmakta ve karşılık bulmaktadır. Kamuoyu yoklamalarından başka diğer gündem olușturma unsuru olarak kanaat önderleri de önemlidir. Medyada yer alan haber ve bilgilerin topluma aktarılması ve ifade edilmesi kanaat önderlerinin bakış açısı ile şekillenmektedir.

Kanaat Önderleri: Medya araçlarından aktarılan bilginin nasıl algılandığı konusunda kanaat önderleri tarafından medya içeriklerinin topluma ulaşmasında ve yorumlanmasında önemli bir etkiye sahiptir. Bu bakımdan medya siyaset ilişkisinde bu yönüyle aktarılan bilgi ve haber, kurgulara dönüşmekte ve bireyler bunları yansıtılan şekilde algılamaktadırlar. $\mathrm{Bu}$ sürece kanaat önderleri dahil olduğunda ise toplumsal ayırım daha kesin hatlarla ortaya çıkmaktadır. Çünkü belli bir siyasal değerin savunucusu durumunda olan kanaat önderleri kendi taraflılıklarına uygun medyadan aldıkları haber ve bilgileri daha da pekiştirerek insanlara aktarabilirler (Güllüpunar, 2011, s. 196). Dolayısıyla medyanın gündem oluşturmak amacıyla kanaat önderleriyle ilişkileri de bu anlamda önem taşımaktadır. Medyanın haber aktarımının kanaat önderleri tarafından nasıl okunduğu ve nasıl anlamlandırdı ğı da önemli hale gelmektedir.

Toplumda yer edinen kanaat önderleri; toplumun kesimlerinde etkisi olan siyasiler, sanatçılar, gazeteciler, dini liderler, sivil toplum kuruluşları ve gruplar olarak ele alınabilir. Kanaat önderleri gündemi takip eden, tüm gelişmeler hakkında bilgi sahibi olan, gündemi meşgul eden konular veya sorunlar ile ilgili düşüncelerini ifade edebilen, toplumun itibar ettiği ve toplum tarafından kabul gören kişi veya gruplardan oluşmaktadır. Aynı zamanda toplumu etkileme gücünü de kültürel ve geleneksel unsurlardan aldığı varsayılan kanaat önderleri, hem siyasiler için hem de medya için önem taşımaktadır. Gündemin nasıl algılandığı veya nasıl yönlendirileceği kanaat önderleri ile nasıl diyalog kurulduğuna ve kanaat önderinin toplum tarafından karşılığına göre de şekillenmektedir.

\subsection{Güç Unsuru Olarak Tekelleşme}

Siyasi ve ekonomik çıkarların en ön sırada yer aldığı 20. yüzyılda hem teknolojik yenilikler hem yüksek baskı sayısı ve izlenme oranını yakalama, hem de ucuza getirme çabaları, sermaye sıkıntısını da beraberinde getirmiştir. $\mathrm{Bu}$ durum ise bazı küçük bütçeli kurumların yok olmasına, bazılarının da birleşmesine yol açarak yeni medya öznelerinin piyasada ve siyasi arenada söz sahibi ${ }^{3}$ olmalarına sebep olmaktadır (Taşkıran, 2007, s. 35).

Medyada tekelleşme eğilimleri görüldügünde medyanın temel işlevi bütünüyle aksamakta, yani nesnel, objektif bilgiyi taşıma ve aktarma işlevi bütünüyle bozulmaktadır. Tekellerin kendi özel tercihleri, özel yargıları, kendi hesaplarına aktardıkları bilgiye de 
yansımaktadır. Eğer medyada böyle bir tekelleşme eğilimi varsa medyadan topluma yansıyan bütün bilginin çarpıtıldığı, bozulduğu ve medyadaki tekellerin sadece kullanıcı ile kendi arasında değil, bütün toplumla kendi iletişiminde enformasyon akımını bozduğu görülmektedir. Dolayısıyla medyada tekelleşme, toplumsal bir doku bozukluğuna yol açmaktadır (Berksoy, 1996'dan aktaran Aytaliyeva, 2010, s. 36). Bunun yanında haber ve iletişim anlamında tarafsızlık ve özgürlükten bahsedebilmek için birçok kanalın (radyo, televizyon, internet vb.) ekonomik bir takım endişelerden uzak olması gerekmektedir. $\mathrm{Bu}$ açıdan, gazete, dergi, televizyon ve radyoların Türkiye'de çoğalması olumlu görülmesine rağmen sayısal açıdan çoğalan bu medya türleri birkaç kişinin egemenliği altında olursa, çoğulculuktan veya haber alma özgürlüğünden bahsetmek mümkün olabilir mi?

Bu bağlamda tekelleşmeyle medya, şirketleşmeyi ve ekonomik hayatta söz sahibi olmayı hızlandırdığı gibi siyaseti şekillendirmeyi ve istenilen düzenin oluşmasını arzulamaktadır. Dolayısıyla tekelleşme, birçok alanda söz sahibi bir medyayı ${ }^{4}$ beraberinde getirmektedir. 1994 yılından beri yapılacak olan frekans ihalesinin yapılamamış olmasi ${ }^{5}$ da bunu doğrular niteliktedir. Medyanın güdümündeki hareket etmek durumunda kalan siyasiler, medya için önemli argümanları içermektedir. Siyasilerin bu durumu göz ardı etmedikleri, aksine çok fazla dikkate aldıkları görülmektedir. Medyanın talep ve beklentilerine uygun düzenlemeler ve kararlar almak konusunda siyasilerin hızlı davranabildikleri ve oluşturulan ortama uyum sağladıkları görülmektedir.

\subsection{Denetleme Gücü Olarak Kamu Denetçiliği}

Kamu denetçisi (ombudsman), kavram olarak sözcü, temsilci, başkaları için şikayet eden kişi anlamına gelen İsveç kökenli bir sözcüktür. Bu anlamda ombudsmanın Türkçe karşılığı olarak; arabulucu, kamu hakemi, medeni hakların savunucusu, parlamento komiseri vb. adlandırmalarla kamu denetçisi kavramı kullanılmaktadır (Aydın vd., 2012, s. 70). Özde bir denetim anlayışı olarak ortaya çıkan ombudsman diğer denetim unsurlarının yetersiz kaldığı, çözüm üretemediği noktalarda her iki taraf için kabul edilebilir çözüm önerileri getirme imkanına sahiptir (Avşar, 2012, s. 107).

Yönetenle yönetilenler arasında araç olarak medya, bir taraftan yönetime halkın dilek ve şikâyetlerini duyururken, diğer taraftan da yönetimin aldığı karar ve tedbirleri kamuoyuna ulaştırmaktadır (Acar, 2009, s. 26). Denetim rolü üstlenen medya, kamuoyunun siyasetten sormak istediklerini, siyasetin aldığı kararlarda kamuoyunun nasıl etkilendiğini, kanun ve siyasi yönetimin icraatlarının kamuoyunda nasıl yansıdığını siyasete yansıtmak amacıyla kamu denetçiliği görevini üstlenmektedir. Dolayısıyla ombudsman diğer adıyla kamu denetçisi, kamuoyunu okuyabilmekte ve kamuoyundan güç almaktadır. Bu bağlamda medya, kamuoyu adına kamu denetçisi rolünü üstlenmekte ve siyasilere karşı bu gücünü kullanmaktadır. Daha önce medya yazarları, kamuoyu tarafından kabul gören kişiler ve siyasetçiler tarafından uygulanan kamu denetçiliği görevi Türkiye'de artık meclis çatısı altında yer almaktadır ${ }^{6}$.

\subsection{Kamu Yararına Yönelik Araştırmacı Gazetecilik}

Araștırmacı gazetecilik, 19. yüzyılın sonlarına doğru ortaya çıkmış; güç odaklarının bilinmesini istemedikleri, ancak bilinmesinde kamu yararı bulunan olguları sistematik bir araştırma ile ve belgeleriyle ortaya çıkarıp kamuya sunmayı uğraş edinen bir gazetecilik pratiğidir. Geleneksel gazetecilikten başlangıcı, amacı, ilgi alanı, zaman kullanımı ve ahlaki vizyonu bakımından ayrılmaktadır. Aucoin'e göre; gerçek araştırmacı gazeteciliğin amacı, toplumsal öfkeyi harekete geçirecek şekilde yasa dışı işlere ilişkin haberleri yayımlamak ve kamu yararı söz konusu olan sistemsel sorunlara odaklanmaktır. Araștırmacı gazetecilik, 
daha önceden bilinmeyen ya da bilinmesi istenmeyen toplum açısından önemli olaylara/ sorunlara ilişkin özgün habercilik șeklinde tanımlanmaktadır (İrvan, 2018, s. 70-72).

Araştırmacı gazetecilik çalışmaları neticesinde ortaya çıkan yeni duruma göre siyasilerin tutum ve tavırlarının da değiştiğini söylemek mümkündür. Sonuç itibariyle yapılan habercilik anlayışı, kamuoyunda ciddi karşılık bulabilir ve belki de kamu lehine siyasette değişmelere ve gelişmelere işılk tutabilir. Siyaset sahnesinde yaşananlarla ilişkilendirilen Susurluk $^{7}$ Kazası gibi bir takım olaylar bu anlamda araştırmacı gazeteciliğe örnek teşkil edebilir.

\section{Medya ve Siyaset İlişkisinde Siyasetin Yeri}

Siyasal elitlerin medyaya bakışında önemli bir etken meşruiyet ihtiyacıdır. Kendilerini ve politikalarını meşrulaştırabilmek ve olumlu imaj geliştirerek rakiplerinden bir adım öne geçmek anlamında medyayla ilgilenmektedirler (Meyer, 2002, s. 74). Siyasetin modern zamanlarda kendi kulvarlarında yürümesini sağlayan en önemli gelişmelerden biri de kitle iletişim araçlarının bütün görkemiyle ortaya çıkışlarıdır (Bostancı, 1998, s. 160).

Siyasilerin iletişim araçlarıyla devamlı ilgilenmelerine neden olan unsurları üç sinıfta toplamak mümkündür (Charon, 1993, s. 241):

- İlk olarak iletişim araçlarının ikna gücüne inanma,

- İkinci olarak parlamenter sistemdeki demokratik toplumlar için görüşmelerin sağlanması gerekliliği,

- Son olarak ta kamuoyu oluşturabilmek için düşünceler, eylemler ve olaylar üzerine birtakım çalışmaların gerçekleşmesinde kitle iletişim araçlarının etkililiğine duyulan inanç.

\section{1. İkna ve Tanıtım Açısından Propaganda}

Siyasiler kamuoyunu ikna etmek için birçok teknik kullanmaktadırlar. İletilecek mesajların ikna edici olması ve kamuoyunda karşılık bulması da önemlidir. Propaganda, siyasetin tercih ettiği tekniklerdendir. Medyanın bu anlamda değerlendirilmesi söz konusudur. İnandırıcı olan ve güvenilir kaynakların sunduğu, verdiği haber ve bilgiler kamuoyunda etkili olmaktadır. Haberin ve bilginin doğruluğundan ziyade etkili olarak sunulması ve sürekli tekrar edilmesi propagandanın özelliklerindendir. Önemli olan inandırıcı olabilmesidir.

Brown'a göre, toplumun görüşünü, tutum ve davranışlarını, belirli bir görüşü ve davranışı benimseyecek biçimde etkilemeyi amaçlayan propaganda da hedef, kitledir ve kitle için kullanılan dildir; radyo, televizyon ya da sinema kanalıyla kitleye ulaștırılan sözler veya daha başka semboller kullanır. Propaganda olgusu, bilgilerin içeriği ve sunuluş tarzına bağlı olarak ortaya çıkmaktadır (Taşdelen, 1997, s. 199).

Edward Herman ve Noam Chomsky, medya vurgularının ${ }^{8}$ muhalif sesleri marjinalleştirerek hükümet politikalarını ve büyük firmaların kararlarını nasıl desteklediğini ortaya koyan bir propaganda modeli taslağı çıkarmaktadır. Medyanın demokratik toplumlarda devlet müdahalesinden görece bağımsız olduğu söylenebilir bu da doğrudur; fakat güncel olayları bildirim kanalları açısından medya hiçbir koşulda tarafsız veya önyargısız değildir. Bu anlamda propaganda modeli beș 'yeni süzgeç'ten meydana gelmektedir (Laughey, 2010, s. 78-79): 
Kitlesel Medyanın Büyüklüğü ve Mülkiyeti: Medya kuruluşlarının büyük bir çoğunluğu tamamen veya kısmen sermayelerini çeşitli iş alanlarına yönelten belli başlı şirketlerin mülkiyetindedir. Medya kuruluşları faaliyet alanlarında ilerlemelerine rıza gösterecek hükümetlere ve mevcut bulunan büyük firmalara bağlıdırlar. Bundan dolayı da hükümetin ya da büyük kuruluşların bakış açılarını kabul eder bir politikanın içinde bulunurlar.

Gerekli Reklâm Ruhsatı: Medya kuruluşları ticari olarak gelir kaynakları açısından reklama bağımlıdırlar ${ }^{9}$ ve bu sebeple de ürünlerini reklâm verenler tarafından ideal olarak kabul edilen kitlenin beğenisine sunmak durumundadırlar. İstenilen kitleye ulaşamayan ve reklam verenler tarafından tercih edilmeyecek olan medyanın saygınlığl, haberci veya yapımcılardan daha çok reklâm verenlerin insafına bağlı kalmaktadır.

Haber Medyasının Kaynağı: Haberlerin asıl kaynağı hükümetler tarafından sunulan resmi bilgilerdir. Güvenilir ve erişilebilir olduğu için bu kanallar medya kuruluşları açısından her zaman özel bir konumdadır. Muhalif kanalların bakışını yansıtan az bilindik kanalların izini sürmek konusunda medya kuruluşları isteksiz davranmakta ve kaçınılmaz bir şekilde propaganda görevi gören resmi kaynaklardan bilgileri tercih etmektedir.

Eleştiri: Gelir ve içerik açısından ilişkilerini sürdürdügü güçlü ticari ve siyasi kuruluşlara fazlasıyla bağımlı olan medya kuruluşları kendisini ilgilendiren önyargı ve yasadışı eylem suçlamaları söz konusu olduğunda nesnellik ve tarafsızlık kurallarının çiğnenmesine ilişkin baskıya rıza göstermek mecburiyetindedir.

Karşıtlık Ídeolojisi: Hükümetlerin ve ticari güçlerin kendi toplumlarındaki eşitsizliği artıran ayrımcı politikalarını aklamak için başvurulan bir denetim mekanizmasıdır.

\subsection{Medya Emperyalizmi}

Emperyalizm, ulusların siyasi ve askeri güç kullanarak diğer ulusları istila etme ve sömürgeleștirme aşamalarıdır (Laughey, 2010, s. 74). Büyük ölçüde kaynak ülkelerin ve kültürlerin hegemonik bir güç halini almasında etkili olmaktadır. Bu süreç, küreselleşme boyutunun da desteğini alarak kendini meşrulaștırmaya çalışmaktadır. Medya araçları bu yönüyle ulusal sınırlar ve kültür içerisindeki yaşamı dönüştürmekte, bir taraftan da küresel boyutta da uluslararası tüketim ve kültür endüstri ağının can damarı olarak işlevini sürdürmektedir (Çelik, 2004, s. 78). Medya, yaşanan dönemin ekonomik biçimi ve üretim ilişkileri tarafından belirlenmesine rağmen kitle iletişim süreçlerinin dönemsel olarak farklılaşmasına neden olsa da temel işlevleri devam etmektedir. Farklı araçlar kullansalar da temel olarak egemen üretim biçiminin yeniden üretimini ve üretim araçlarına sahip olan sınıfın ideolojik aygıtı olmayı sürdürürler (Çoban, 2013).

Bir başka açıdan, kitle iletişim araçlarının üretim ve yayılımında gelişmiş ulusların üstün konumu, ister istemez bir iletişim araçları emperyalizminden bahsetmeye sebep olmaktadır (Çelik, 2004, s. 78). Medya emperyalizmi ulusların medya iletişimini kullanarak diğer ulusların kültürel değerlerini denetim ve baskı altına alma sürecidir (Laughey, 2010, s. 74). Siyasi yapılanmanın teknolojik yapıyı kullanarak giderek güçlenmesi, iletişim sahasının da totaliterleşmesi ve tüketimden başka bir şey düşünmeyen insanlardan meydana gelen bir yığının oluşması riskini beraberinde getirmektedir (Çoban, 2013).

Emperyalizm, dünyada güçlü ve büyük ülkelerin diğer ülkelere gücünü ve baskısını hissettirmek için ortaya koyduğu ve uyguladığı bir yoldur. Bu amaçla kullandığı araçlardan biri veya en önemlisi olarak medya, egemen gücün tüm unsurlarını yansıtan 
bir ortamdır. Dolayısıyla, medya siyasi güçlerin ya da odakların amaçları doğrultusunda hareket etmektedir.

\section{Türkiye'de Siyasetin Medya Alanındaki Düzenlemeleri}

Siyasi unsurlar medya gücünü ellerinde bulundurmak ve medyaya tamamen hâkim olmak amacıyla medyanın hareket alanını sınırlandırmak ve medyayı denetim altına almak istemektedirler. Hangi yönetim anlayışında olursa olsun medyanın yanında yer almasını isteyen siyasi güç medyayı yönlendirmekte ve bir takım yaptırımlar uygulayarak kendine bağlı kılmaya çalışmaktadır. Bunlardan yola çıkarak, özellikle haber alma/ verme ve kamu denetçiliği ve araştırmacı gazetecilik görevi üstlenecek olan medyaya yönelik yapılan baskılar ve oluşturulan denetimler siyasi yapılanmalara göre çeşitlilik arz etmesine rağmen genel olarak sansür uygulaması, kanunlarla denetim bu alanda en yaygın kullanılan tahakküm araçlarıdır.

Türkiye'de ise kanun ve yönetmeliklere bakıldığında, bu sürecin her dönem ișlediği ve iktidarda bulunan güç odaklarına medyanın hizmet ettirilmeye zorlandığı görülmektedir. Bunları bir takım medya isteyerek yapar iken yani iktidarın sözcülügüne soyunmuş iken bir takım medya ise, ya patronları aracılığıyla ya da editör ekibi tarafından susturulmuş, sindirilmiş ve seslerini duyuramaz olmuşlardır. Bu her dönem farklı işlemekte fakat sonuç hiç değişmemektedir. Burada önemli olan medyanın siyasal gücün kontrolünü kabul etmek durumunda olmasıdır. Siyasi gücün elinde çok önemli bir koz bulunmaktadır. Yasama yani kanun yapma ve değiştirme yetkisi bu anlamda siyasal gücün medya üzerinde en önemli baskı unsurudur. Bu baskı unsurlarına kurullar, yönetmelik ve kanunlardan örnek vermemiz mümkündür.

\subsection{Kurullar}

\subsubsection{Radyo ve Televizyon Üst Kurulu (RTÜK) ${ }^{10}$}

Ülkemizde özel radyo ve televizyon yayınları 1990 yılından itibaren herhangi bir yasal düzenlemeye tabi olmaksızın başlamıştır. 1993 yılında Anayasa değişikliği yapılarak radyo ve televizyon yayınları üzerindeki kamu tekeli ortadan kaldırılmış, özel radyo ve televizyon yayınlarının yapılmasına olanak sağlanmıştır. Özel radyo ve televizyon yayınlarını düzenleyen Mülga 3984 Sayılı Radyo ve Televizyonların Kuruluş ve Yayınları Hakkında Kanun'un 1994 yılında yürürlüğe girmesiyle, Radyo ve Televizyon Üst Kurulu kurulmuştur. Üst Kurul, dokuz üyeden oluşmaktadır. Radyo ve Televizyon Üst Kurulu, radyo ve televizyon faaliyetlerini düzenlemek ve denetlemekle görevli, Anayasanın 133. maddesi kapsamında üyeleri TBMM Genel Kurulunca seçilen, özerk ve tarafsız bir kamu tüzel kişiliğidir.

Ülkemizde karasal, sayısal, uydu, kablo ve IPTV ortamından yayın yapacak kuruluşlara lisans ve yayın izni Radyo ve Televizyon Üst Kurulu tarafından verilmektedir. Radyo ve televizyon yayınları; RTÜK Uzmanları tarafından yapılan doğrudan denetim, 4441178 RTÜK İletişim Merkezi, RTÜK web ve RTÜK e-posta kanallarından gelen izleyici şikâyetlerinin değerlendirilmesi yoluyla yapılan izleyici denetimi ve İzleyici Temsilciliği müessesesi ve Yayıncılık Etik İlkeleri bağlamında yayın kuruluşlarının yaptığı özdenetim olmak üzere üç şekilde denetlenmektedir.

Radyo, televizyon ve isteğe bağlı yayın hizmetleri; 6112 Sayılı Kanuna, Avrupa Sınır Ötesi Televizyon Sözleşmesi gibi taraf olunan milletlerarası antlaşmalara ve ilgili yönetmeliklere uygunluk açısından denetlenmektedir. Üst Kurul programlara yayından önce müdahale edemez, ancak yayından sonra denetleyebilir. Denetimde izleyici şikâyetlerini ve 
başvurularını da dikkate alır, gerek görürse müeyyide uygular. Kurulun bütün kararları, idari yargının denetimine açıktır.

\subsubsection{Bilgi Teknolojileri ve İletişim Kurumu (BTK) ${ }^{11}$}

Telekomünikasyon sektörünü düzenleme ve denetleme fonksiyonunun bağımsız bir idari otorite tarafından yürütülmesi amacıyla 2813 sayılı Telsiz Kanunu'nda değişiklik yapan 27.1.2000 tarihli ve 4502 sayılı Kanunla kurulan Telekomünikasyon Kurumu, 10.11.2008 tarihli ve 5809 sayılı Elektronik Haberleşme Kanunu ile yeni bir düzenlemeye tabi olmuş ve adı Bilgi Teknolojileri ve İletişim Kurumu olarak değiștirilmiştir.

Bilgi Teknolojileri ve İletişim Kurumu, 5809 sayılı Elektronik Haberleșme Kanunu kapsamında işletmecilerin aldıkları lisans sözleşmelerinin şartlarına uyup uymadıklarını, kişisel telekomünikasyon tesislerinin kullandıkları teçhizatların standartlara uygunluğu ve telekomünikasyon sektörünün ilgili mevzuata uyup uymadığını denetlenmektedir. $\mathrm{Bu}$ kapsamda, düzenlemelere uymayan işletmecilere müeyyide uygulanabilmektedir. Bilgi Teknolojileri ve İletişim Kurumu, denetleme işlevini düzenleme denetlemeleri, spektrum izleme ve denetleme, piyasa gözetimi ve denetimi, elektronik sertifika hizmet sağlayıcılarının denetimi başlıkları altında yürütmektedir.

\subsection{Yönetmelikler}

\subsubsection{Sansür Yönetmeliği ${ }^{12}$}

Bakanlar Kurulu Kararı doğrultusunda 1966 yılında çıkarılan yönetmelik, savaş halinde veya sıkıyönetim altına alınan yerlerde sansüre tabi maddelerle, sansür için gerekli yöntemleri açıklamak için çıkarılmıştır. Buna göre sansürün amacı;

- Kamu düzeni ve güvenini bozan, halkı telaş ve heyecana düşürecek nitelik taşıyan haberlerin yayılmasını önlemek.

- Milli Güvenlik bakımından gizli kalması gerekli bilgi ve haberlerin duyulmasına ve yayılmasına engel olmak.

- Milli Güvenlik yönünden faydalı olabilecek bilgileri elde etmek.

27. Maddede basılmış eserlerin, 28. Maddede radyo televizyon yayınlarının, 29. Maddede sinema ve film senaryolarının, 30. Maddede tiyatro ve tiyatro eserlerinin, 31. Maddede Plaklar, fonopost maddeleri ve basılmış müzik eserlerinin sansür edilebileceği anlatılmaktadır.

Ayrıca bu yönetmeliğin Bakanlar Kurulu tarafından yürütüldüğü, savaş halinin veya sıkıyönetimin sona ermesi ile veya Başkomutanlık ve sıkıyönetim komutanlığının emirleri ile uygulanmasının durdurulabileceği madde 41. de ifade edilmektedir.

Bu sansür yönetmeliği 2012 yılında yürürlükten kaldırılmıştır ${ }^{13}$.

\subsubsection{Radyo, Televizyon ve İsteğe Bağı Yayınların İnternet Ortamından Sunumu Hakkında Yönetmelik' ${ }^{14}$}

30849 sayılı Resmi Gazete'de yayınlanarak yürürlüğe giren yönetmelik, internet ortamında yayın yapan medya hizmet sağlayıcıların denetlenmesini içermektedir. Bu Yönetmeliğin amacl; radyo, televizyon ve isteğe bağlı yayın hizmetlerinin internet ortamından sunumuna, iletimine, medya hizmet sağlayıcılara yayın lisansı, platform işletmecilerine de yayın iletim yetkisi verilmesine ve söz konusu yayınların denetlenmesine ilişkin usul ve esasları belirlemektir. Bu Yönetmelik, radyo, televizyon ve isteğe bağlı yayın hizmetlerinin internet ortamından sunumu ile bu yayın hizmetlerini internet ortamından sunan özel 
medya hizmet sağlayıcı kuruluşları ve bu yayın hizmetlerinin iletimini sağlayan platform işletmecilerini kapsar.

\subsection{Kanunlar}

\subsubsection{Basın Kanunu ${ }^{15}$ (5187 sayılı)}

Amacı, basın özgürlüğünü ve bu özgürlüğün kullanımını düzenlemek olan Basın Kanunu, basılmış eserlerin basımı ve yayımını kapsayacak şekilde 9.6.2004 tarihinde kabul edilmiştir.

Kanunun 3. Maddesi’nde “Basın özgürdür. Bu özgürlük; bilgi edinme, yayma, eleştirme, yorumlama ve eser yaratma haklarını içerir. Basın özgürlügünün kullanılması ancak demokratik bir toplumun gereklerine uygun olarak; başkalarının şöhret ve haklarının, toplum sağlığının ve ahlâkının, millî güvenlik, kamu düzeni, kamu güvenliği ve toprak bütünlüğünün korunması, Devlet sırlarının açıklanmasının veya suç işlenmesinin önlenmesi, yargı gücünün otorite ve tarafsızlığının sağlanması amacıyla sınırlanabilir" hükmü gereğince basın özgürlüğü ele alınmaktadır.

Ayrıca, kanunda beyanname verme, cezai ve hukuki sorumluluklar, düzeltme ve cevap hakkı ile ilgili hükümler, yargıyı etkileme, el koyma, dağıtım ve satış yasağı, basılmış eserleri engelleme tahrip etme vb. maddeler yer almaktadır.

\subsubsection{Fikir ve Sanat Eserleri Kanunu' ${ }^{16}$ ( 5846 Sayılı)}

05/12/1951 yılında yayınlanan ve günümüze kadar bir takım güncelleştirmeler yapılan bu Kanunun amacı, fikir ve sanat eserlerini meydana getiren eser sahipleri ile bu eserleri icra eden veya yorumlayan icracı sanatçlların, seslerin ilk tespitini yapan fonogram yapımcıları ile filmlerin ilk tespitini gerçekleştiren yapımcıların ve radyo-televizyon kuruluşlarının ürünleri üzerindeki manevi ve mali haklarını belirlemek, korumak, bu ürünlerden yararlanma şartlarını düzenlemek, öngörülen esas ve usullere aykırı yararlanma halinde yaptırımları tespit etmek, yargı yollarını ve yaptırımları ile Kültür Bakanlığının görev, yetki ve sorumluluğunu kapsamaktadır.

Fikir ve sanat eserleri kanunu ile kitle iletişim araçlarının kullanmak istedikleri fikir ve sanat eserlerini bir kural, esas ve usullere göre kullanması, kanun koyucu tarafından takip edilerek denetlenmektedir.

\subsubsection{Kişisel Verilerin Korunması Kanunu ${ }^{17}$ (6698 Sayılı)}

2016 yılında yayınlanan bu Kanun'un amacı, kişisel verilerin işlenmesinde başta özel hayatın gizliliği olmak üzere kişilerin temel hak ve özgürlüklerini korumak ve kişisel verileri işleyen gerçek ve tüzel kişilerin yükümlülükleri ile uyacakları usul ve esasları düzenlemektir. Bu Kanun hükümleri, kişisel verileri işlenen gerçek kişiler ile bu verileri tamamen veya kısmen alan ve otomatik olan ya da herhangi bir veri kayıt sisteminin parçası olmak kaydıyla otomatik olmayan yollarla işleyen gerçek ve tüzel kişiler hakkında uygulanır.

$\mathrm{Bu}$ kanun, kişisel verilerin korunması, bireylerin hakkını korumak açısından önemlidir. İstenilmeyen görüntü, ses ve kayıtların yine istenilmeyen yayıncı mecralara taşınmasının ya da bilgilerinin işlenilerek kişi hakkında veri bankası oluşturulmasının önüne geçmek amaçlanmaktadır. Bu durumda, kitle iletişim araçlarının haber değeri olsa bile bu tür durumlara karşı ihtiyatlı olmasını beraberinde getirecektir. Medyanın bu hususlarda dikkatli olması idari para cezası vb. yaptırımla karşılaşmalarının önüne geçebilir. 


\subsubsection{Küçükleri Muzır Neşriyattan Koruma Kanunu' ${ }^{18}$ (1117 Sayılı)}

18 yaşından küçüklerin maneviyatı üzerinde muzır tesir yapacağı anlaşılan mevkute (süreli yayın) ve mevkute tanımına girmeyen diğer basılmış eserlere yönelik sınırlamaları içeren kanun 21/06/1927 yılında kabul edilmiş ve birçok defalar yeni maddeler eklenerek bu güne kadar gelmiştir.

Sınırlamalar için, Çalışma, Sosyal Hizmetler ve Aile Bakanlığı bünyesinde oluşturulan yetkili kurulun, söz konusu eserlerin 18 yaşından küçükler için muzır olduğu hakkında bir karar vermesi gereklidir. Kurul, basılmıș eserlerin küçükler için muzır olup olmadığı hususunda yapacağı incelemede, 1739 sayılı Milli Eğitim Temel Kanunu'ndaki genel amaç ve temel ilkeleri göz önünde bulundurmak zorundadır. Kurul, bu Kanunla kendisine verilen görevlere ilaveten, Türk Ceza Kanununun 426, 427 ve 428'inci maddelerinde tanımlanan suçlarla ilgili olarak yargı organlarına resmi bilirkişilik yapmakla görevlidir. Ayrıca Kanunun 4. maddesinde bu eserlerin nasıl satılması gerektiği ve küçük çocukların bunlardan nasıl korunacağı ifade edilmektedir.

\subsection{5. İnternet Ortamında Yapılan Yayınların Düzenlenmesi ve Bu Yayınlar Yoluyla İşlenen Suçlarla Mücadele Edilmesi Hakkında Kanun ${ }^{19}$ (5651 Sayılı)}

$\mathrm{Bu}$ Kanunun amaç ve kapsamı; içerik sağlayıcı, yer sağlayıcı, erişim sağlayıcı ve toplu kullanım sağlayıcıların yükümlülük ve sorumlulukları ile internet ortamında işlenen belirli suçlarla içerik, yer ve erişim sağlayıcıları üzerinden mücadeleye ilişkin esas ve usulleri düzenlemektir.

İçerik, yer ve erişim sağlayıcıları, yönetmelikle belirlenen esas ve usuller çerçevesinde tanıtıcı bilgilerini kendilerine ait internet ortamında kullanıcıların ulaşabileceği şekilde ve güncel olarak bulundurmakla yükümlüdür. Erişim sağlayıcının yükümlülükleri, 6 . Maddede ayrıntılarıyla ifade edilmektedir.

İnternet ortamında yapılan ve içeriği hangi suçların oluşturduğu hususunda yeterli şüphe sebebi bulunan yayınlarla ilgili olarak erişimin engellenmesine karar verilir denilerek erişimin engellenmesi kararı ve yerine getirilmesi 8. Madde de, içeriğin yayından çıkarılması ve erişimin engellenmesi de 9. maddede ayrıntılı bir şekilde açıklanmaktadır.

\subsubsection{Elektronik Haberleşme Kanunu²0 (5809 sayılı)}

$\mathrm{Bu}$ Kanunun amacl; elektronik haberleşme sektöründe düzenleme ve denetleme yoluyla etkin rekabetin tesisi, tüketici haklarının gözetilmesi, ülke genelinde hizmetlerin yaygınlaştırılması, kaynakların etkin ve verimli kullanılması, haberleşme alt yapı, şebeke ve hizmet alanında teknolojik gelişimin ve yeni yatırımların teşvik edilmesi ve bunlara ilişkin usul ve esasların belirlenmesidir.

Denetim, 59. Madde de "Kurum re'sen veya kendisine intikal eden ihbar veya şikayet üzerine, bu Kanunda belirlenen görevleri ile ilgili olarak elektronik haberleşme sektöründe yer alan gerçek ve tüzel kişileri denetleyebilir, denetlettirebilir. Kurum, bu Kanunun kendisine verdiği görevleri yerine getirirken gerekli gördügü hallerde, mahallinde de inceleme ve denetim yapabilir ve/veya yaptırabilir" șeklinde ifade edilmektedir.

Kurumun Yetkisi ve İdari Yaptırımlar 60. Madde de "Kurum; mevzuata, kullanım hakkı ve diğer yetkilendirme şartlarına uyulmasını izleme ve denetlemeye, aykırılık halinde işletmecilere bir önceki takvim yılındaki net satışlarının yüzde üçüne kadar idarî para cezası uygulamaya, millî güvenlik, kamu düzeni veya kamu hizmetinin gereği gibi yürütülmesi ve kanunlarla getirilen hükümlerin uygulanması amaçlarıyla gerekli 
tedbirleri almaya, gerektiğinde tesisleri tazminat karşılığında devralmaya, belirlediği süre içerisinde yetkilendirme ücretinin ödenmemesi ya da ağır kusur halinde verdiği yetkilendirmeyi iptal etmeye yetkilidir." biçiminde yer almaktadır.

\section{Sonuç}

Medya siyasetten bağımsız, siyaset medyadan ayrı değildir. Medya siyaset ilişkisi hangi yönetim sistemi olursa olsun mutlaka devam eden bir süreçtir. Medya, totaliter ve otoriter türü rejimlerde siyasi iktidarın sesi ve yayın organı gibi hareket etmekte, liberal ve demokratik rejimlerde de kanun ve düzenlemelerin öne çıktığı bir durum ortaya çıkmaktadır. Tarafsız ve bağımsız medya kuruluşlarının içinde bulunduğu ortam veya durum ise iktidarın yapısına ve bakış tarzına göre şekillenmektedir. Tekelleşme ve bunun yanında kartelleşmeye kadar varacak durumlar medya siyaset ilişkisini etkilemektedir. Siyasetin medyaya bakışı ise propaganda ve fikirlerini ya da kültürünü yayma şeklinde medya emperyalizmi denen unsurlarının devreye girmesiyle ortaya çıkmaktadır.

Dolayısıyla medya ve siyaset, her zaman ve her durumda sürekli etkileşim ve iletişim içinde olmak zorundadır. Siyasetin medya gücü ve desteğinden faydalanması ya da medyanın siyaseti kendi lehine kullanması ve sürekli etkileşimin getirdiği durumların değerlendirilmesi; insanların medyayı nasıl okuması veya nasıl görmesi gerektiği açısından önem taşımaktadır. Medyanın gerçekten haber verme ve kamuoyunu bilgilendirme fonksiyonu, siyasetle ilişkisi bağlamında değerlendirilmelidir. Siyasetin istediği ya da öne sürdüğü çalışmaları, faaliyetleri ulaştırmak için medyaya baskı yapmak amacıyla birtakım düzenlemeleri kullanması ve bu düzenlemeleri medyanın tepesinde bir kılıç gibi tutması medyanın tarafsızlığını ve objektif haber sunma gücünü zayıflatacaktır. Siyaset, medyayı tahakküm altında tutmak amacıyla yönetmelikler ve kanuni düzenlemeler yaparak, medyanın işleyişini denetleyen bir takım kurumlara yetki ve güç vererek medyanın hareket edebilme gücünü sınırlamakta ve kısıtlamaktadır. $\mathrm{Bu}$ tamamen siyasetin güçlü olduğu dönemlerde ortaya çıkmaktadır.

Sonuç olarak medya ve siyaset üzerine siyasal iktidarların meşruluğunu ya da medyanın meşruluğunu sağlayıcı gücünü nasıl aldıklarını iyi bir şekilde ele alabilmek, gücün kullanımı açısından yapılan tartışmanın doğru okunmasını sağlayacaktır. Medya ve siyasetin devamı ve meşruluğunu sağlamak adına birbirlerine ihtiyaçları olduğu bir gerçektir. Çok uzun yıllardır tartışması devam eden medya ve siyaset ilişkisine bu çalışma, siyasetin medya üzerinde oluşturduğu baskı unsurları açısından bakmaya çalışmış ve sonucunda siyasetin her zaman medyayı baskılayabileceği ve istediği gibi hareket etmediği takdirde elinde bulunan yasama gücü ile bunu kendi lehine yönlendirebileceği üzerinde durulmuştur. Bundan sonraki çalışmalar için medya ve siyaset ilişkisinde bu bakış açısının, bir anlamda yeni çalışmalara yol göstermesi beklenebilir.

\section{Notlar}

1 Medi@Ware: 2012-2014 yılları arasında AB Çerçeve Programları Destekli Proje bünyesinde "Medya ve Siyaset Üzerine" adılı çalışma.

2 Kartel: Tekelci sermaye piyasasında, birtakım ticaret, üretim kuruluşlarıın, genellikle kazanma veya başka kuruluşlara karşı tutunabilme vb. amaçlarla aralarında kurdukları dayanışma birliği (TDK, 2013).

3 Bu duruma en güzel örnek olarak Cem Uzan'ın yükselişi verilebilir. Türkiye'nin ilk ticarî ve beraberinde korsan televizyon kanalı olan Star'ın ortaklarından birinin Cem Uzan olması tesadüfî değildir. 1990'lı yıllarda hız kazanan özelleştirme politikalarının sonucunda Uzan ailesi hem ilişkilerini hem de özel bir televizyon kanalına hatta kanallarına sahip olmanın avantajıı kullanarak özelleştirme ihalelerinde en ön saflarda yer almaya başlamıştır. Enerji ve çimento sektörü, Uzan Grubu'nun en çok ilgi gösterdiği alanlar olmuştur. Finans sektöründe de önce İmar Bankası, sonrasında da Adabank ile boy göstermişlerdir. Telekomünikasyon alanında ise, Telsim ile GSM sektörüne girmişlerdir. Türkiye süper liginde yer 
alan İstanbulspor ve Adanaspor sahipliğine kadar uzanan süreçte; bir de yazııı basın alanında Star ve Damga gazetesini yayımlayarak dağıtım, reklâm ve ilân alanındaki pastadan da pay almaya başlamıştı. Bununla birlikte, Uzan Grubu'nun 46. kuruluş yıldönümü kutlamalarılya Türkiye'de büyük ve orta ölçekli kent meydanlarının konserlerle ele geçirilmesi süreci, beraberinde yeni bir siyasal partinin habercisi olmuştur. Genç Parti'nin, Türkiye'deki siyasal yaşama katılışı asında bir oldubittiye getirilmiştir. Üç aylık gibi kısa bir zaman diliminde, Genç Parti'nin bir başka siyasal partiye el koyması yoluyla 3 Kasım 2002 milletvekili genel seçimlerine girerek, seçmenden yüzde 7.2 gibi yüksek bir oranda oy alabilmeyi başarmışıtır. Bu durum, Türkiye'deki mevcut siyaset ortamının gösterilmesinin ve Cem Uzan'ı destekleyen, sahibi olduğu medyanın sergilediği işlevselliğin irdelenmesi açısından dikkate değer bir örnek olarak önem kazanmaktadır (Yaylagül ve Dağtaş, 2004, s. 486-487).

4 Türkiye'de sermayenin yoğunlaşması ve tekelleşmeyle birlikte, siyasetin şekillenmesi ve toplumun siyasal olarak yönlendirilmesinde medya önemli bir güç haline gelmiştir. Kimi medya kuruluşlarının sahipleri belli siyasal hareketleri destekleyip, onlarla menfaat ilişkisine girerken; kimi medya sahipleri de doğrudan kendileri siyasal hayata atılarak, kontrol ettikleri medyayı amaçlarını gerçekleştirmede bir araç olarak kullanmaktadır. Italyan medya patronu Berlusconi'nin, İtalya'da sahibi olduğu medyanın desteğiyle başbakanlığa yükselmesi, bu duruma somut bir örnek oluşturmaktadır. Türkiye'de ise, 3 Kasım 2002 genel seçimleri öncesinde Genç Parti'yi kuran ve sahibi olduğu medya kanalları vasıtasıyla propaganda faaliyetini sürdüren Cem Uzan benzer bir hedefi ve eğilimi sergilemektedir. İtalya'da "Forza Italia" adlı parti, Berlusconi'nin çok büyük çaplı, tekelci bir medya gücüne dayanarak, ticarî ve siyasi fonksiyonlarının iç içe geçtiği bir kadro kullanımıyla büyük bir politik güçç haline gelmiştir (Yaylagül ve Dağtaş, 2004, s. 486).

52013 yılında ihaleler yapılmaya başlanmış ve kanallar belli olmuş fakat yine yargı engeline takılmıştır. (Ayrıntılı haber için bakını http://www.haber7.com/gundem/haber/1029436-frekans-ihalesi-yargidan-donduhttp://www.turktime.com/ haber/RTUK-un-Frekans-Ihalesi-Mahkemelik-Oldu/221989/http://yenisafak.com.tr/gundem-haber/frekans-ihalesinedurdurma-22.05.2013 523722, 2013).

6 Kamu Denetçiliği Kurumu, Anayasanın 74. maddesinde yer alan Anayasal bir Kurumdur. 6328 sayılı Kanunun 5. Maddesi gereğince "Kurum, idarenin işleyişi ile ilgili şikâyet üzerine, idarenin her türlü eylem ve işlemleri ile tutum ve davranışlarını; insan haklarına dayalı adalet anlayışı içinde, hukuka ve hakkaniyete uygunluk yönlerinden incelemek, araştırmak ve idareye önerilerde bulunmakla..." görevlendirilmiştir. Kurum, Hukukun üstünlüğünün sağlanması, iyi yönetim ilkelerinin yerleştirilmesi ve halka karşı sorumluluk anlayışı içinde ve hakkaniyet temelinde, Türkiye Büyük Millet Meclisi'ne bağı bir denetim mekanizması olarak 2013 yılından itibaren faaliyetlerini sürdürmekte, halkın avukatlığını yapmakta ve aldığı kararlar ile idareye yol göstermektedir. (https://www.ombudsman.gov.tr/hakkimizda/index.html, 2018)

7 Susurluk kazası, Türkiye'nin çok yakın geçmişine damgasını vurmuştur. Susurluk'tan sonra gelişmeye başlayan olaylara kamuoyunun tavrı, siyasi partilerin olayın üzerine gitmesi vs. konular Türkiye'de hükümet ve rejim krizi olduğu yolundaki değerlendirmelere kadar uzanmıştır. Oysa, Susurluk'tan sonra devletin içinde bir çetenin bulunduğu, çete, bünyesinde polis teşkilatı, bazı illegal örgüt mensupları ve devlet yetkililerinin görev aldığı yolundaki iddia ve değerlendirmeler siyasetten ekonomiye kadar pek çok sektörde kırılmaların yaşanmasına yol açmışıtı. Şu anda Türkiye'nin içinde bulunduğu siyasi kırımaların arka planında Susurluk'tan sonraki gelişmelerin önemli payı vardır ve bunda basının rolü azımsanmayacak derecede çoktur (Karakoç, 2002, s. 151).

8 Sermayenin ve egemen güçlerin ortak çıkarları, kitle iletişim araçlarında, çoğu zaman gerçek öneme sahip haberlerin akışını engellemekte ve insanlara asında fazla bir şey ifade etmeyen büyük miktarda bilgi yüklemektedir. Reklâm veren kuruluşların, medya holdinglerinin patronlarının ve hükümetin birbirinin içine geçen menfaatleri doğrultusunda belirlenen medya içeriği, hem rızanın üretilmesini sağlamakta, hem de insanlara belirli bir yaşam tarzını ve dünya görüşünü empoze etmektedir. Buradan hareketle, sorgulama yapar isek akla şunlar gelmektedir: Kararlarımızı etkileyen, bize gerekli enformasyonu sağlamakla sorumlu olduğu söylenen medya, aslında tarafsı değilse ve bize gerçeği söylemiyorsa; biz her gün televizyon izlerken ya da gazete okurken bize belirli bir ideolojiyi ya da hayat tarzını empoze eden sistemli bir propagandaya maruz kalıyorsak; gerçek öneme sahip haberler bize ulaşamıyorsa ve biz yalnızca öğrenmemize izin verilenleri öğreniyorsak; dahası, bütün bu olan bitenin içinde sıkışıp kaldığımız sistemin farkında bile değilsek, demokrasideki özgür bireyden ve bağımsız seçimlerden ne kadar bahsetmek yerinde olur? (Muratoğlu, 2011, s. 10-11).

9 Reklamcılar, medya şirketlerinin en önemli gelir kaynağını sağlayan kesimdir. Televizyonların yayın akışları reklâmlara göre düzenlenmekte, reklâm içerikleri de televizyon türlerine göre üretilmekte; reklamcıları rahatsız edecek kimi unsurlar akışa veya programa sokulmamaktadır. Reklamcıların medyayı kontrol etmesiyle ilgili olarak bilinen belki de en ilginç örnek, Nürnberg Savaş Suçları Mahkemelerini konu alan bir televizyon filmiyle ilgilidir. Filme sponsorluk yapan Amerikan gaz şirketi, faşist Almanya'da Yahudilerin gaz odalarına gönderilmeleriyle ilgili bölümlerin filmden çıkarılmasını talep etmiş̧ir. Bu tür referanslar, doğaldır ki gaz şirketinin itibarını/imajını zedeleyecektir... (Murdock, 1977'den aktaran Adakı, 2013, s. 72).

10 RTÜK hakkında daha fazla bilgi için bakınız (http://www.rtuk.org.tr, 2013).

11 BTK hakkında daha fazla bilgi için bakınız (https://www.btk.gov.tr/2018). 
12 Uygulanan sansür girişimleri için bir örnek teşkil etmekte olan bu yönetmelik için bakınız (www.resmigazete.gov.tr/ arsiv/12345.pdf, 2016).

13 Sansür Yönetmeliğinin Yürürlükten Kaldırımasına Dair Yönetmelik'in yürürlüğe konulması; Milli Savunma Bakanlığının 25/9/2012 tarihli ve 1751 sayııı yazııı üzerine, Bakanlar Kurulu'nca 4/10/2012 tarihinde kararlaştııımışıır. Bakınız http://www.resmigazete.gov.tr/eskiler/2012/10/20121030-9. htm, 2013).

14 Yönetmelik için bakınız https://www.resmigazete.gov.tr/eskiler/2019/08/20190801-5.htm, 2020

15 Kanun hakkındaki bilgiler için bakınız (http://www.tbmm.gov.tr/kanunlar/k5187.html, 2013).

16 Kanuna ulaşmak için bakınız (http://www.mevzuat.adalet.gov.tr/html/957.html,2013).

17 Kanun hakkında bakınız (https://www.mevzuat.gov.tr/MevzuatMetin/1.5.6698.pdf, 2020).

18 Kanuna ulaşmak için bakınız (http://www.mevzuat.adalet.gov.tr/html/438.html, 2013).

19 Kanun hakkında bilgi edinmek için bakınız (https://www.mevzuat.gov.tr/MevzuatMetin/1.5.5651.pdf, 2017)

20 Kanun hakkında bilgi edinmek için bakınız (https://www.mevzuat.gov.tr/MevzuatMetin/1.5.5809.pdf, 2019)

\section{Kaynakça}

Acar, T. (2009). Kamu Yönetiminde Yeni Bir Denetim Yolu: Kamu Denetçiliği Kurumu [Yayınlanmamış Yüksek Lisans Tezi]. Süleyman Demirel Üniversitesi Sosyal Bilimler Enstitüsü Kamu Yönetimi Anabilim Dalı.

Adaklı, G. (2013). Gazetecilik Etiğini Belirleyen Yapısal Sorunlar: Mülkiyet ve Kontrol Sorunu. http://ilef.ankara.edu.tr/etik/wp-content/uploads/gulseren-adakli-gazeteciliketigini-belirleyen-yapisal-unsurlar-mulkiyet-ve-kontrol-sorunu. pdf, Erişim Tarihi: 10.06.2013.

Arabacı, C. (2004). Basın ve Siyaset Üzerine.... İçinde M. Işık (Ed.), Medyada Yeni Yaklaşımlar (ss. 105-128). Konya: Eğitim Yayınları.

Avşar, B. Z. (2012). Ombusdman/Kamu Denetçisi. İstanbul: Hayat Yayınları.

Aydın, A. H., Taş, İ. E., ve Ersöz, M. (2012). Önemi ve Uygulanabilirliği Açısından Türkiye'de Kamu Denetçiliği Kurumu. Turgut Özal Uluslararası Ekonomi ve Siyaset Kongresi II: Küresel Değișim ve Demokratikleşme, Malatya.

Aytaliyeva, T. (2010). Medya Dünyasında Tekelleşme: Türkiye Örneği. Türkiye Manas Üniversitesi Sosyal Bilimler Enstitüsü İletişim Ana Bilim Dalı.

Balcı, Ş., Tarhan, A., \& Bal, E. (2013). Medya ve Siyasal Katılım. Konya: Literatürk Yayınları.

Basın Kanunu. (2004) http://www.tbmm.gov.tr/kanunlar/k5187.html, Erișim Tarihi: 15.03.2013.

Bilgi Teknolojileri ve İletişim Kurumu. (2008). https://www.btk.gov.tr, Erişim Tarihi:15.04.2018).

Bostancı, N. (1998). Siyaset, Medya ve Ötesi. Ankara: Vadi Yayınları.

Charon, J. M. (1993). İletişim Araçlarında Devlet Müdahalesi. Içinde J.-M. Charon (Ed.), \& O. Tatlıpınar (Çev.), Medya Dünyası (s. 243-245). İstanbul: İletişim Yayınları.

Çelik, C. (2004). Kitle İletişim Araçları ve Popüler Kültür İlişkisine Sosyolojik Bir Yaklaşım. İçinde M. Işık (Ed.), Medyada Yeni Yaklaşımlar (s. 67-82). Konya: Eğitim Yayınları.

Çoban, B. (2013). Yeni Emperyalizm Çağında Yeni Medya: Küreselleșme Sürecinde Medya Eleştirisi.,http://www.academia.edu/609132/YENI_EMPERYALIZM_CAGINDA_ YENI_MEDYA, Erişim Tarihi:15.05.2013. 
Damlapınar, Z. (2007). Medya ve Siyaset İlişkilerinde Temel Yaklaşımlar, İlköğretim Medya Okuryazarlığı Dersi Öğretmen El Kitabı. Ankara: RTÜK Araştırma Geliștirme Daire Başkanlığı.

Damlapınar, Z. (2008). Medya ve Siyasete Güvenilirlik: Medya Siyaseti'nin Toplumsal Algılanmasına Bağlı Faktörler. İçinde Z. Damlapınar (Ed.), Medya ve Siyaset (s. 187207). Konya: Eğitim Yayınları.

Elektronik Haberleşme Kanunu (2008) (https://www.mevzuat.gov.tr/ MevzuatMetin/1.5.5809.pdf, Erişim Tarihi: 15.01. 2019.

Fikir ve Sanat Eserleri Kanunu (1951) http://www.mevzuat.adalet.gov.tr/ html/957. html, Erişim Tarihi:14.03.2013.

Güllüpunar, H. (2011). Siyasal Sosyalizasyon Sürecinde Medya Faktörü ve Siyasallaşan Medyanın Ergenekon Davasında Oluşturduğu Algı Farklılıkları: Gümüşhane Kamuoyu Önderleri Araştırması. II. Medya ve Etik Sempozyumu, 195-203.

Güz, N. (2005). Haberde Yönlendirme ve Kamuoyu Araştırmaları. Ankara: Nobel Yayın Dağıtım.

Hazar, Ç. M. (2008). Medya ve Siyasal Sistemin Kaos Yorumu. İçinde Zülfikar Damlapınar (Ed.), Medya ve Siyaset (s. 245-259). Konya: Eğitim Yayınları.

http://www.haber7.com/gundem/haber/1029436-frekans-ihalesi-yargidan-dondu, Erişim Tarihi 15.03.2013.

http://www.turktime.com/haber/RTUK-un-Frekans-Ihalesi-Mahkemelik-Oldu/ 221989/, Erişim Tarihi 15.03.2013.

http: / / yenis afak.com.tr/gundem - haber/frekans-ihalesinedurdurma-22.05.2013-523722, Erişim Tarihi 15.03.2013.

İnternet Ortamında Yapılan Yayınların Düzenlenmesi ve Bu Yayınlar Yoluyla İşlenen Suçlarla Mücadele Edilmesi Hakkında Kanun (2007) https://www.mevzuat.gov.tr/ MevzuatMetin/1.5.5651.pdf, Erişim Tarihi: 15.04.2017.

İrvan, S. (2018). Araştırmacı Gazetecilik: Kavramsal Bir Değerlendirme. Etkileşim, 1(2), 70-94.

Kamu Denetçiliği Kurumu (2013) (https://www.ombudsman.gov.tr/ hakkimizda/index. html, Erişim Tarihi:13.03. 2018).

Karakoç, E. (2002). Basının Kamuoyunu Oluşturma Fonksiyonu (Örnek Olay: Susurluk). Selçuk İletişim, 2(2), 150-167.

Kapani, M. (1997). Politika Bilimine Giriş. Ankara: Bilgi Yayınevi.

Kaya, R. (1985). Kitle İletişim Sistemleri. Ankara: Teori Yayınları

Kişisel Verileri Koruma Kanunu (2016) https://www.mevzuat.gov.tr/ MevzuatMetin/1.5.6698.pdf, Erişim Tarihi 15.03.2020.

Küçükleri Muzır Neşriyattan Koruma Kanunu (1927) http://www.mevzuat.adalet. gov.tr/ html/438.html, Erişim Tarihi:13.03.2013.

Laughey, D. (2010). Medya Çalışmaları Teoriler ve Yaklaşımlar (A. Toprak, Çev.). İstanbul: Kalkedon Yayıncılık.

McQuail, D. (1994). Kitle İletişim Kuramı. Eskişehir: Anadolu Üniversitesi Yayınları. 
Meyer, T. (Lew Hinchman'la Birlikte) (2002). Medya Demokrasisi (A. Fethi, Çev.). İstanbul: Türkiye İş Bankası Kültür Yayınları.

Milburn, M. A. (1998). Sosyal Psikolojik Açıdan Kamuoyu ve Siyaset (A. Dönmez \& V. Duyan, Çev.). Ankara: İmge Yayınları.

Muratoğlu, B. (2011). Bir Demokrasi Masalı: Özgür Birey, Bağımsız Medya. PÍVOLKA, 20(6), 9-11.

Radyo ve Televizyon Üst Kurulu (1994), http://www.rtuk.org.tr/sayfalar/ IcerikGoster.aspx?icerik_id=80775e05-caec-4a48-bac5-39fd6375da3b, Erişim Tarihi:15.03.2013.

Radyo, Televizyon Ve İsteğe Bağlı Yayınların İnternet Ortamından Sunumu Hakkında Yönetmelik (2019) https://www.resmigazete.gov.tr/ eskiler/2019/08/20190801-5.htm, Erișim Tarihi: 14.03.2020.

Sansür Yönetmeliği (1966) https://www.resmigazete.gov.tr/arsiv/12345.pdf, Erişim Tarihi: 14.03.2016.

Severin, J. W., ve Tankard, W. J. (1994). İletişim Kuramları: Kökenleri, Yöntemleri ve Kitle İletişim Araçlarında Kullanımları (A. A. Bir ve N. S. Sever, Çev.). Eskişehir: Kibele Sanat Merkezi.

Siebert, F. T., Peterson, T., \& Schramm, W. (1963). Four Theories of the Press. Urbana: University of Illinois Press.

Taşdelen, H. M. (1997). Siyaset Sosyolojisi. İstanbul: Kocav Yayıncılık.

Taşkıran, N. Ö. (2007). Medya Okuryazarlığına Giriş. İstanbul: Beta Yayım Dağıtım.

TDK. (2013). Güncel Sözlük. http://www.tdk.gov.tr, Erişim Tarihi: (s. 10.06.2013)

Terkan, B. (2005). Gündem Belirleme Medya ve Siyasal Gündem Üzerine Bir Çalışma. Konya: Tablet Yayınları.

Yaylagül, L. (2008). Kitle İletişim Kuramları Egemen ve Eleştirel Yaklaşımlar. Ankara: Dipnot Yayınları.

Yaylagül, L., ve Dağtaș, E. (2004). Medya Patronluğundan Başbakanlığa Yükselme İstekleri: Cem Uzan ve Genç Parti Örnek Olayı. 2nd International Symposium Communication in The Millennium: A Dialogue Between Turkish and American Schoolars Sempozyumu, İstanbul Üniversitesi, 17-19 Mart.

Yengin, H. (1996). Medyanın Dili. İstanbul: Der Yayınları.

Yüksel, E. (2000). Basın ve Siyaset Gündeminde Özelleștirme. Eskișehir: Anadolu Üniversitesi Yayınları.

Yüksel, E. (2001). Medyanın Gündem Belirleme Gücü. Konya: Çizgi Kitabevi Yayınları. 


\title{
A Review of Regulations of Politics in Media Field in Turkey in The Context of Media - Politics Interaction
}

\author{
Mustafa Akdağ (Prof. Dr.)
}

\section{Extended Abstract \\ Introduction}

Media and politics are seen as a non-alternative system that provides public service and is assigned by the society. It is possible to say that both institutions carry out their work on behalf of the society. Institutions that have an inevitable dialectical relationship in this respect should act with the awareness of their responsibilities when examined in terms of relationships and interactions, perspectives and social outcomes within the social system.

The media depends on political power in terms of news source and material. Political power also needs the media to be able to announce its activities and express itself in public. When the dialectical relationship between them is moved to different dimensions, it is taken out of the original mission and objectives of both institutions and returned to interest relations. Examining the legitimacy of political power and media affiliation structures on media and politics can provide an accurate reading of the discussion. The main aim of this study is to explain the relationship between the two institutions and the extent to which each other is interfered with and what the arguments are.

\section{Theories in Media and Politics Relationships}

These theories, also called normative media theories, which emerged in order to understand how the media functions its duty, are grouped into six groups by McQuail: authoritarian, totalitarian, liberal, social responsibility, development and democratic participatory theories.

\section{Media in the relationship between Media and Politics}

The power of the media to influence the social/public perception of political facts, events, controversial issues, institutions and actors begins to make itself more felt with the rise of the age of image. Recently, the formation of politics through the media and the determination of social opinions, and the rapid technological development in the media, which has the power to influence the social credibility of institutions, increase the power of the media and this makes the media inaccessible. The media, which is included in the agenda as a technology of political relations that need to be reproduced in the conditions of mass society, does not have the authority to make laws despite its power, a special relationship with the politicians appears and the bosses of the media, who have this serious power, try to prevent free and accurate news reception and at the same time, it tries to form the agenda one way, that is, it begins to control the news and information for the continuation of its sovereignty. It is seen as controlling and creating the agenda to create public opinion, form a cartel by monopolizing or even going further, and act as an audit on behalf of the public, as well as investigative journalism.

\section{Politics in the relationship between Media and Politics}

Those in politics are interested in the media in order to legitimize themselves and their policies and to take a step ahead of their competitors by developing a positive image. It 
is possible to gather the factors that cause politicians to be interested in communication means in three classes:

- First, to believe in the persuasive power of the means of communication,

- Secondly, the necessity for negotiations for democratic societies in the parliamentary system,

- Finally, the belief in the effectiveness of mass media in the realization of some studies on thoughts, actions and events in order to create public opinion.

The media, which is used within the framework of the power, diameter and effectiveness of all power focuses, is used to say, show and present everything that is intended to be said. In this respect, the media can be regarded as an extremely powerful source of persuasion, publicity and propaganda.

Based on these, although the pressures and audits made especially for the media, which will serve as the public auditor, vary according to the political structures, censorship is the most widely used means of domination in this area. It is possible to give examples of these pressure elements from censorship regulations, RTÜK(The Supreme Board of Radio and Television), BTK(Information and Information Technologies Authority) and laws.

\section{Conclusion}

The media is not independent of politics and politics is not separate from the media. The relationship between media and politics is an ongoing process regardless of the management system. The media acts as the voice and broadcaster of political power in totalitarian and authoritarian regimes, and in liberal and democratic regimes a situation arises in which laws and regulations come to the fore. The environment or situation in which neutral and independent media organizations are located is shaped according to the structure and view of the power. Monopoly as well as the situations that will reach cartelization affect the relationship between the media and politics. The approach of politics to the media is revealed by the introduction of elements called media imperialism in the form of propaganda and spreading their ideas or culture. Therefore, media and politics have to be in constant interaction and communication at all times and in all situations. The importance of media literacy arises in cases where politics benefits from media power and support or the media uses politics to its advantage. Assessing situations brought about by constant interaction is important in terms of how people should read or view the media. The actual function of the media to inform and enlighten the public should be evaluated in the context of its relation to politics. The use of certain regulations in order to pressure the media to deliver the work or activities that politics wants or proposes, and to hold these regulations as a sword at the top of the media, will undermine the impartiality of the media and its power to deliver objective news.

Keywords: Communication, Media, Politics, Media and Politics Relationship. 